\title{
THE EFFECTS OF NEUROLINGUISTIC PROGRAMMING (NLP) METHODS TOWARDS STUDENTS' SPEAKING SKILL
}

\author{
Mildan Arsdan Fidinillah \\ Program of English Education, Faculty of Language and Art, University of Indraprasta PGRI \\ Jalan Nangka No. 58C Tanjung Barat, Jagakarsa, South Jakarta 12530 \\ mildan_fidinillah@yahoo.com
}

\begin{abstract}
The objective of this research is to investigate the effects of Neurolinguistic Programming (NLP) method towards students' speaking skill at Madrasah Ibtidaiyah Sa'adatuddarain 2 Tangerang Selatan. This research was conducted at Madrasah Ibtidaiyah Sa'adatuddarain 2 Tangerang Selatan from April 15 $5^{\text {th }}$ 2016-July $15^{\text {th }} 2016$. By using purposive sampling technique, 60 out of 300 students of grade $\mathrm{V}$ in school year 2015-2016 were chosen. The method used was a survey with a correlational technique. The instrument included one test to analyze the data quantitatively. Test is used to assess the students' speaking skill. There is a positive and significant impact of students that learning using NLP method in the ability of speaking English. Furthermore, $\alpha=0.05, \mathrm{df}=19$, and t-table $=1.73$, while $t_{\text {count }}=9,26$. Thus $t_{\text {count }}>t_{\text {table }}$, this means that $\mathrm{H}_{0}$ is rejected and $\mathrm{H}_{1}$ is accepted, As conclusion, NLP method affects positively and significantly to the students' speaking English ability compared with conventional method.
\end{abstract}

Key words: Neurolinguistic Programming (NLP) method, speaking skill, English learning

\begin{abstract}
ABSTRAK
Tujuan dari dari penelitian ini adalah untuk mengetahui efek metode Neurolinguistic Programming (NLP) terhadap kemampuan berbicara bahasa Inggris siswa di Madrasah Ibtidaiyah Sa'adatuddarain 2 Tangerang Selatan. Penelitian ini dilakukan di Madrasah Ibtidaiyah Sa'adatuddarain 2 Tangerang Selatan dari 15 April 2016 - 15 Juli 2016. Dengan menggunakan teknik pengambilan sample secara purposive, 60 dari 300 siswa kelas V angkatan 2015-2016 dipilih. Metode yang digunakan adalah survey dengan teknik korelasi. Instrumen yang digunakan adalah satu buah tes yang dibagikan kepada responden sebagai bagian dari penelitian kuantitatif. Test berbicara (speaking test) dipakai untuk mengukur kemampuan berbicara bahasa Inggris siswa. Dari perhitungan statistik diperoleh $\alpha=0.05, d f=19$, dan t-table $=1.73$, sementara thitung $=$ 9, 26. Dengan demikian $t_{\text {hitung }}>t_{\text {tabel }}$, ini berarti $H_{0}$ ditolak dan $H_{1}$ diterima. Sebagai kesimpulan, NLP method memberikan dampak yang positif dan signifikan terhadap kemampuan berbicara bahasa inggris siswa bila dibandingkan dengan metode konvensional.
\end{abstract}

Kata kunci: Metode Neurolinguistic Programming (NLP), kemampuan berbicara, pembelajaran Bahasa Inggris 


\section{INTRODUCTION}

Indonesia has a strategic location for trading and transit base. To advantage, the mastery of some languages is needed. One of the common languages used internationally is English. English language has a very important function for the humans being. As the second rank of number language speakers, English becomes the key to the international communication. Most people around the world use English to communicate with other people from other countries which absolutely have different language. It causes everybody is demanded to learn English.

Tourism is one of the sectors which use English as a universal language. It is because of the spread of English in some countries, such Malaysia, Singapore, Japan, and Korea. Therefore, many people who travel from one country to another must need a language which can be accepted and understood by the people that they meet. Another sector which uses the role of English is education. Lots of all books and materials that are studied in many countries use English language. Some foods which are consumed by people all over the world mostly has English name, such as burger, curry, and bread.

In international trading, English takes a big part in communication. To make the ordering and purchasing become easier, the specification of products are usually explained in English. The last sector which uses the function of English is the expansion of automotive. Almost all of the spare parts are named in English, although some of them are produced in the countries that do not use English as their main or second language. From the sectors above, the function of English can be shown as an international language which makes the communication between countries becomes easier.

Since Independence Day, the government of Indonesia has placed English language teaching as one of the compulsory subjects in the school. The government of Indonesia has placed an important role in determining the school curriculum, textbooks, teachers, and so on. The school based-curriculum, comprising English curriculum, as endorsed by the Department of National Education of the Republic of Indonesia has recently been implemented from Elementary to High Schools in the country. In Senior High School or SMA (Sekolah Menengah Atas), the learning process is divided across three grades with each competence which students should reach.

The government of Indonesia has changed the English curriculum five times. The first curriculum was introduced in 1945; it was a grammartranslation-based curriculum. The second curriculum was introduced in 1958; this was an audio-lingual based curriculum. This was based on the involvement of Ford Foundation of the United States. The next curriculum applied in the Indonesian education in 1975 was the revised new style, audiolingual based curriculum. The government, for the first time, introduced new textbook series for the Junior High School and Senior High School. Later, in 1984, the new curriculum was launched, which was a structure-based communicative skill. The teaching method at that time focused on memorizing the words. The Department of Education then revised the 1984 curriculum with the new curriculum, in 1944. During this time, communicative approach was mostly used in the schools around the world. 
The curriculum of 1984 and 1994 achieved the same result; firstly, the curriculum contents focus mostly on reading comprehension materials despite an attempt to integrate the four skills to accommodate the changing orientation to a focus on productive skills; secondly, the national examination still used the same format as in 1984, that is reading and formbased multiple-choice question.

There are four basics of English language skills; listening, speaking, reading, and writing, which can be classified into two parameters. According to the mode of communication, there are oral and written languages. Yet, another parameter is based on the direction of communication; producing and receiving the message. Each skill cannot be separated in learning a language. They should be learned as a unity to complete each other. The first skill to master in order to be proficient in language is listening. It belongs to the receptive skill in the oral mode.

People get the first information through listening to the speaker, because no one can say before they listen. Listening is not only defined as hearing something, but also understanding the message that is given. Listening skill is connected to speaking skill, because it can improve someone's knowledge and the ability of speaking. But, different with listening, speaking is the productive skill in the oral mode. People usually show their feeling, thought, and needs through speaking.

Although speaking is not only about how people pronounce the words, it still becomes the easiest way in expressing what is in the mind. It has known that the ability of speaking is dependent to the listening skill. Another skill that must be mastered in learning language is reading. It has similar type of listening; they are the receptive skill, but in the written mode. It causes reading can develop independently of listening and speaking skill.

Through the reading skill, people can build their vocabularies and learn the written structures of language. Even though reading is generally after listening and speaking, it can take a big part in learning process, especially in accessing information from written text. The last basic skill of language is writing. It is a productive skill in written mode. Similar with speaking, writing also has very close relationship with reading, its partner. They are in writing form which related to the spelling and grammar. All of those skills are better to be dealt by the English learners.

Reading is often defined as a process of receiving and interpreting information from printed media. Because print is all around the people, we use it in many more ways than we are aware of. The implication of printed media is magazines, signs, newspapers, flyers, books, posters, movie titles, and many others. People read them either consciously intend to read, or just seem to pick up or encounter.

The combination of daily encounters with texts and needs to read in different ways in educational and professional settings requires that people read differently depending on the context and goals (and motivation). When people read for different purposes, they engage in many types of reading, particularly in academic settings. First, reading is purposed to search for information. It only needs a simple quick understanding of the text, called scanning and skimming. The second purpose is for quick understanding, i.e. skimming. People could skim when they want to determine what a text is about and 
whether or not they want to spend more time reading it.

The next purpose is reading to learn, which is often carried out in academic and professional settings. People read to learn when the information in a text is identified as important (often by a teacher or textbook) and when that information will be used for some task or may be needed in the future. Fourth, reading to integrate information which requires that the reader synthesize (and learn) information from multiple texts or bring together information from different parts of a long text, such a long and complex chapter in a textbook. In this purpose, readers must organize the ideas which come from multiple texts; it means that they have to link much information and build the understanding about topics they encounter.

In the case of multiple texts, the reader must decide which aspects to select, prioritize, and highlight, and then create a coherent organizational frame around the full set of information to be synthesized. Reading to evaluate, critique, and use information often also represents an increased level of demand and a more complex interaction of reading processes. In this aim of reading, readers need to decide how to relate the text information to other information inter textually and to their prior knowledge and beliefs. Last, the most common purpose for reading among fluent readers is reading for general comprehension. This is reading that takes place when people read a good novel, an interesting newspaper story or feature article, or a magazine when they are relaxing.

In fact, reading for general comprehension involves a complex set of processes. It is true that general comprehension processes provide a foundation for other reading purposes, such as reading to learn and reading to evaluate. But reading for general comprehension is also a type of reading that is carried out automatically for extended periods of time and with apparently few processing difficulties.

In a foreign language class, reading is one of the main sources of the input for the learners. The ability of reading allows the students to continue developing other skills that they have acquired in the classroom. The reading skill becomes one of the most important elements of learning English because someone can learn and improve their knowledge in English such as vocabulary and grammar through reading.

However, reading is not a simple thing to do, especially in foreign language. There are many possible reasons why students think that reading in English is difficult. First, it comes from the limited reader's knowledge of English; consequently, the reader needs to be able in guessing or predicting the hindered meaning of the materials. Nevertheless, the wrong choice of the cues or the uncertainty of the choice will make the association more difficult. Due to unfamiliarity of the material and the lack of training, the memory span in a foreign language in the early stages of its acquisition is usually shorter than in our native language; recollection of previous cues then, is more difficult in a foreign than in mother tongue. In addition, there is interference of our native language, Bahasa Indonesia, which has its own style of writing.

These factors show that the problems of foreign language readers are mainly on the knowledge of the foreign language itself and the interference from the first language. In order to reach the comprehension in reading English, teachers have to use some techniques which can also 
motivate students to read the texts, although it seems difficult for them. One of the techniques is mind map. It is a graphic tool which represents words, images, or ideas that spread out into branches which is linked to central keyword or idea. Mind map has been applied for several years. It could guide the students to clarify the structure of the article and the links between paragraphs. Therefore, it can help the students to understand the reading materials, encourage their development of reading, and empower their cooperation between students.

The writer observed the students of Madrasah Ibtidaiyah Sa'adatuddarain 2 Tangerang Selatan for last three months during the teaching learning process of English in the classroom where he found that there are some factors influenced the students' speaking skill in English such as the appropiate method chosen by teacher. The writer realized in the term of it where method of teaching as a tool to transfer knowledge from teacher to students must having precision. When a teacher teaches the students speaking with unappropiate method, so at the end of the teaching learning process, the objective of the learning can not be reached. If an objective of learning that can not be gained by both teacher and students, it is mean that the whole learning process is considerely failure.

There are a lot of methods in teaching English speaking for students. An ideal teacher will always change the method to teach speaking to accelerate the students' mastery to this skill. English as EFL setting likes in Indonesian is commented by people through two aspects are speaking and writing where a student tends to be fluently both in speaking and writing skill will get a judgment from people that he is able in English. As a result, there are some factors assumed contributing to the students' speaking skill in English i.e. method to teach speaking. Therefore, this study aims to investigate whether there is any effect between Neurolinguistic Programming (NLP) Methods towards students' speaking skill in English at Madrasah Ibtidaiyah Sa'adatuddarain 2 Tangerang Selatan.

Language is not an abstract construction of the learned, or of dictionary-makers, but is something arising out of the work, needs, ties, joys, offections, tastes, of long generations of humanity, and has its bases broad and low, close to the ground. The authors analyze the language not only has the construction in learning but in the language itself also has its own value, but not only in the learning process.

The language in the theory of an abstract idea. Abstract is an adjective that means intangible, not obvious, and others. Language is called abstract because of the intangible and invisible, but set on a particular object. Referring to certain objects in this case the language is always used. But just as a transmitter to provide information.

As a building has a construction or order. Because construction is beginning to do something that was planned. This theory also stated that not only language that contains a view of construction that are not visible but can be said to be the language of the dictionary or create a new meaning, especially in language learners. Every time we use the language in their work, expressed a desire, taste and others. Unwittingly every generation or young people continued to digest. There may be creatures God created not speak. Although it is said that man has a limited ability to speak. All around, we always use the language. 
From start to humans, animals, plants. Sometimes the only man who was using the language. Animals also have a language understood by them, just as it is the same plant. Each creature must have had language, especially humans also have a language that can be developed in accordance with the opinion of Brown (2007:16), "Language is a complex, specialized skill, which develops in the child spontaneously, without conscious effort or formal instruction, is deploy without awareness of its underlying logic, is qualitatively the same in every individual, and is distinct from more general stabilities to process information or behave intelligently". The authors analyze that language is made directly or said to be spontaneous and not contrived.

Complex interpreted language means the language is presented in full. But not all languages are presented incomplete or complex because only on specific skills. Human beings are born into the world through two processes, namely: growth and development. Growth means humans continue to grow, starting from the body. While the developments are not recognized and does not appear visible.

One of these developments in the process of speaking. The language is intended from the language of the gestures, the so-called body language. Language performance by the body. Then the language was done directly by mouth. Humans also practice speaking for the express purpose to be conveyed.

Submission of language do not realize it because every single human being is not calculated how much to say. Language is done without conscious logic then included into the quality or qualitative. Every single human being is different in the receiving language. The following opinion was expressed by Jackson (2011:3), "Language is a special form of verbal communication used by a particular group of listeners. Then the authors analyze that almost the same as the previous experts that language is a verbal capabilities similar to spontaneous or carried out directly". Verbal communication is usually done by humans began as a child. Things that do like learning to read around, reading books, learning to write, and others. Verbal communication can also be called a communication spontaneously or directly carried out in the language.

In studying the human condition is categorized in a few, there are likely on writing, reading, speaking, writing, and listening. But in the opinion of these experts reveal the condition of a particular listener. Of the three experts, the authors propose a language is something that is not just abstract, but that also can be absorbed verbal skills and can also be done spontaneously.

Speaking generally means a delivery intentions (ideas, thoughts, hearts) one person to another by using spoken language so that the purpose can be understood by others. Definition in particular often mentioned by experts Brown (2004:140), for example, said: "Speaking is a productive skill that can be directly and empirically observed", that speaking is a skill that is generated directly or manufactured directly by each individual which is based on research or observations gained from experience.

In the process of talking preferred because it is important to use, as the expert opinion Luoma (2009:1), which argued: "Speaking skills are an important part of the curriculum in language teaching, and this makes them an important object of assessment as well". Besides important means also the ability to speak must follow the 
curriculum, especially for language teaching. Therefore, of all the expert opinions, the author describes the opinion of speaking is a skill that is productive because it is produced directly in the form of oral more inclined towards the comparison refers to a particular curriculum language teaching.

In here there is assessment speaking. Assessment is an ongoing process that encompasses a much wider domain. Whenever a student responds to a question, offers a comment, or tries out a new word or structure, the teacher subconsciously makes an assessment of students' performance. "Written workfrom a jotted down phrase to a formal essay is performance that ultimately is assessed by self, teacher and possibly other students" (Brown, 2003:4). Referring to the opinion means that teachers must often actively assess the student's ability to speak.

In the assessment there are also several categories from Brown, about oral proficiency scores categories, such as: grammar, vocabulary, comprehension, fluency, pronunciation, and task. These categories can be a tool in order to classify students in group based on their English speaking appearance and they will not be only emerged so because each category has its detail which is absolutely able to explain student's capacity described sufficiently regarding every category to consider initial performance of English Speaking. And each gain scoring scale is surely predicted to explain them in detail based on student's achievement to respond every question delivered.

For his assessment of the criteria, namely pressure, grammar, vocabulary, fluency, and comprehension. According to the authors is almost identical to the assessment criteria of previous expert. Then another opinion expressed by
Luoma (2009:4) says "Assessing speaking is a process with stages". The author analyzes that language assessment through a few processes or phases. In the assessment categories include: range, accuracy, fluency, interaction, and coherence. The author analyzes for assessment criteria is almost the same as the previous writer also. Therefore, the opinion of experts from several authors support the theory of Brown and Luoma as interrelated processes or phases talk repeatedly but do not really need the integration in the valuation. Whereas in the case of the three assessment criteria among experts is almost the same with each other.

Besides assessing in speaking, so there are type of speaking, type of speaking from Brown (2003:141) states as "With all effective tests, designing appropriate assessment tasks in speaking begins with the specification of objectives or criteria". Those objectives may be classified in terms of several types of speaking performance. Imitative: At one end of a continuum of types of speaking performance is the ability to simply parrot back (imitate) a word or phrase or possibly a sentence. While this is purely phonetic level of oral production, a number of prosodic, lexical and grammatical properties of language may be conclude in the criterion performance.

Intensive: A second type of speaking frequently employed in assessment contexts is the production of short stretches of oral language designed to demonstrate competence in a narrow band of grammatical, phrasal, lexical of phonological relationship (such as prosodic element-intonation, stress, rhythm, juncture). Examples of extensive assessment tasks include directed response tasks, reading aloud, sentence and dialogue completion limited picture-cued task including 
simple sequences and relationship up to the simple sentence level.

Third type of speaking is responsive assessment tasks included interaction and test comprehension but at the somewhat limited level of very short conversations, standard greetings and a small talk, simple request and comments and the like. Fourth type of speaking is interactive. The difference between responsive and interactive speaking is in the length and complexity of the interaction, which sometimes includes multiple exchange and/or multiple participants. Then fifth from type of speaking is Extensive (monologues). Extensive oral production tasks include speeches, oral production tasks include speeches, oral presentations, and storytelling, during which the opportunity for oral interaction from listeners is either highly limited (perhaps to nonverbal responses) or ruled out together.

Five types of speech, can be described that type of talk adjusted to the students who will be taught and must also consider the age level of students. Technique of teaching speaking mentioned by Patel (2008:104) is that "When teaching oral work or speaking, those are: oral composition, read or look picture carefully, completing story, dramatization, conversational activities, and language game". The author outlines of the sixth technique of this talk, that teachers should set an example first, then tell the students, and touched the hearts of students, then assign a task usually done per group.

Richards dan Roger (2001:145) stated: "NLP is a collection of techniques, patterns, and strategies for assisting effective communication, personal growth and change, and learning". It is the authors analyze that in the NLP there are strategies or techniques, or patterns used for learning so that growth. Then a similar opinion expressed by Millrood (2004: 58/1), "Neuro-linguistic programming (NLP) is an approach to language teaching which is claimed to help achieve excellence in learner performance". In this case is almost the same as the previous theory because NLP is an approach to help students in the learning process in order to obtain outstanding results.

As for the opinion of another expert such as Sailendra (2014: 5), "Dengan linguistik, NLP menunjukkan bahwa neuro atau saraf dapat dipengaruhi oleh bahasa atau kata-kata dalam menafsirkan suatu pengalaman. Adapun pemilihan kata programming bermula dari keyakinan bahwa dalam diri manusia, kita telah mempunyai banyak simpanan program. Bentuk dari program-program ini mewujudkan berupa perilaku, kemampuan, keyakinan, nila-nilai, dan lain-lain". The author argues that a wide range of behaviors, abilities, beliefs, and other value-other that we can change in accordance with the benefits given to us or based on experience. Therefore, the definition can be described NLP is a method for learning more powerful than just experience.

NLP in Language Teaching, Neurolinguistic programming (NLP) in English teaching can be used to help the students become aware at a feeling level of the conceptual meaning of a grammatical structure. Shipman (2003:5) cited by Riyono (2012:1) states that "NLP is about communication". One of the principles of NLP is that we are always communicating, and most of our communication is other than words. In line with this, Revell and Norman (1997:14) cited by Riyono, (2012:1) defined that "NLP is a collection of 
techniques, patterns, and strategies for assisting effective communication, personal growth and change, and learning. It is based on a series of underlying assumption about how the mind works and how people act and interact". In addition, NLP is about how language affects us.

Language affects how we think and respond. The very process of converting experience into language requires that we condense, distort, and summarize how we perceive the world. NLP also provides questions and patterns to make communication more as we intend. Learning language through NLP can also add awareness and consumer protection for your mind. In education, NLP's practical applications include understanding how we learn and developing strategies for both students and teachers. Through NLP, Teachers and parents gain concrete methods for helping the students well in school. Classroom teachers are incorporating key pieces of the NLP approach into their teaching methods and classroom management. Your students' learning styles will be influenced by their genetic make-up, their previous learning experiences, their culture and the society they live in. As teachers, we should be aware that your students have a range of learning styles. There are many ways of looking at learning styles. Here are some of the most widely used classification systems that have been developed. According to Bandler and Grinder in the field of NLP, there are three kinds of learning styles cited by Riyono (2012:1):

"Visual learners, these learners need to see the teacher's body language and facial expression to fully understand the content of a lesson. They tend to prefer sitting at the front of the classroom to avoid visual obstructions (e.g. people's heads). They may think in pictures and learn best from visual display including diagrams, illustrated handout, whiteboard pictures, demonstrations, flipcharts and hand out. During a classroom discussion, visual learning often prefers to take detail notes to absorb the information."

Auditory Learners, they learn best through verbal information delivery, discussions, talking things through and listening to what others have to say. Auditory learners interpret the underlying meanings of speech through listening to tone of voice, pitch, speed and other nuances. Written information may have little meaning until it is heard. Kinesthetic learners, they learn best through a hands-on approach, actively exploring the physical world around them. They may find it hard to sit still for long periods and may become distracted by their need for activity and exploration.

Each type of learning style has different strength and weaknesses, so, a teachers should recognize the students' types of learning well to choose the best treatment for them. In fact, there are many cases that the student tends to be difficult in understanding a topic of lesson not because that he is not smart, but the problem is that the teacher teaches the topic through different types of learning that make the students are not comfort.

According to Revell and Norman cited by Richards and Rodgers (2001:127) there are four key principles lie at the heart of NLP: Outcomes: the goals or ends. NLP claims that knowing precisely what you want helps you achieve it. This principle can be expressed as "know what you want." 
Rapport: a factor that is essential for effective communication-maximizing similarities and minimizing differences between people at a non-conscious level. This principle can be expressed as "Establish rapport with yourself and then with others. Sensory acuity: noticing what another person is communicating, consciously and onverbally. This can be expressed as "use your senses. Look at, listening to, and feel what is actually happening." Flexibility: doing things differently if what you are doing is not working: having a range of skills to do something else or something different. This can be expressed as "keep changing what you do until you get what you want. Therefore, the authors say that to design learning or syllabus should use the four basic principles to achieve the target.

Then application or process NLP, according to Revell and Norman cited by Riyono (2012) presents some presuppositions that guide the application of NLP in language learning and other fields. The idea is that these principles become part of the belief system of the teacher and shape the way teaching is conducted no matter what method the teacher is using. Presupposition (Mind and body are interconnected.) according to this presupposition our mind affects our body and our body affects our mind. If our state of mind is good, we tend to feel good physically too. And the better our body feels, the better our mind functions. Therefore, doing physical activities in the classroom optimizes the learning state of our learners.

Presupposition (the map is not the territory.) according to this presupposition different people believe different things, and what people believe influences what they do and what happens to them. People are also different in how they experience the world and how they represent 'reality' in their mind. Presupposition (the map becomes the territory.) this presupposition in NLP is based on the power of belief and self-fulfilling prophecy. If you believe something to be true, you make it true. This idea is valid both for positive, and for negative beliefs. Giving positive messages rather than negative ones provides self-esteem in yourself as a teacher and your students as learners, and they are able to improve learning.

Presupposition (The resources we need are within us.) according to this presupposition, resources in NLP create positive stimuli like a sense of humor, confidence, patience, good listening skills and so on. Presupposition (communication is non-verbal as well as verbal), Communication is more nonverbal than verbal. Learners of a foreign language also need to notice and practice non-verbal as well as verbal communication. Besides this, teachers are also models of using nonverbal communication. Therefore, the authors say that the application or process is to be achieved presuppositions divide start begins with movement, then give encouragement or positive things, looking for its source so that the level of late students can apply.

\section{METHOD}

Variables examined in this study are: 1) the independent variable is the learning method of Neurolinguistics Programming (NLP), and 2) the dependent variable is speaking skill. This study uses the method of experiment approach. Then the researchers used an experimental method (Post Test-Control Design) and the influence of the treatment will be examined by $t$-test. 


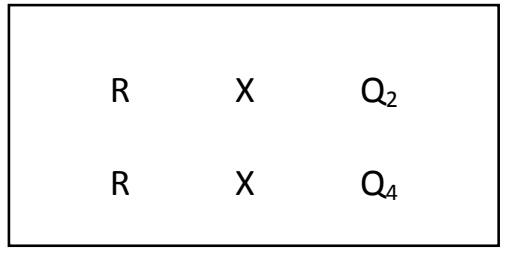

The researcher used one kind of instruments to collect the data. It is one of English tests for speaking skill in English. Data collection techniques used in this study are researchers used Posttest- Control Design, then different teaching against the group. The first group was treat method of Neurolinguistic Programming (NLP) as an experimental group and a second group was given no treatment or use techniques lectures as a control group.

The instrument was the speaking skill test which had made by the English teacher. The numbers of the items are only 20 numbers and each of items has one score. So, the total score is 20 . The higher of the score, the more students intend to be as excellent in mastering English speaking and vice versa. In short, there were two kinds of score. They were score of NLP and score of speaking skill in English. Then, all the data were analyzed by statistical calculation of SPSS.

\section{RESULTS AND DISCUSSION}

For $\alpha=0,05$ and $\mathrm{dk}=19$ obtained from price table of $\mathrm{t}=1,73$ whereas $\mathrm{t}_{\text {count }}=$ 9,26 . Thus $t_{\text {count }}>t_{\text {table }}$, This means that reject $\mathrm{H}_{0}$, accept $\mathrm{H}_{1}$, Thus it can be concluded, that the results of students speaking given NLP method affects positively significantly compared to the students given conventional method.

After the data entered has been processed using statistic, obtained that students given NLP method, the averag value is amounted to 64,76 with a standard deviation of 9.43 . While the students given conventional method, obtained average value amounted to
43.61 with a standard deviation of 12.83. From here it can be seen that students given NLP method are better than students given conventional model. Students taught using NLP method have an average of learning outcomes better. Based on testing using a test normality Liliefors where $L_{0,05(21)}=0,193$ obtained $\mathrm{L}_{0}=0,1813$ in students given conventional method and $\mathrm{L}_{0}=0,1288 \mathrm{in}$ value of speaking given NLP method thus $L_{0}<L_{\text {tabel }}$ then $\mathrm{H}_{0}$ is accepted at $\alpha=0,05$. Thus we can conclude that the sample comes from populations with normal distribution. From the testing of homogeneity of samples to determine whether the sample group is derived from a homogeneous group or not, obtained $F_{\text {hitung }}<F_{\text {tabel }}(1,48<2,12)$, then the two groups of homogeneous samples.

Then, once held hypothesis testing of $\mathrm{t}$ price obtained from the calculation of 9.26. Meanwhile, according to the criteria of hypothesis testing, $\mathrm{H}_{0}$ is accepted if $\mathrm{t}_{\text {count }}$ is between positive and negative value from $t_{\text {table. }}$ Will be tested whether the value of $t_{\text {count }}$ is included in the area of acceptance or not, $t_{\text {count }}$ amounted to 9,26 more than 1,73 . Thus we can conclude that the null hypothesis is rejected and the research hypothesis is accepted at significance level of $5 \%(\alpha=0.05)$. This study therefore has successfully tested the truth of the hypothesis, namely that there is a difference between the results of students' speaking in an interview of the results of speaking using NLP method with students given conventional method.

The results of speaking is the ability to communicate in speaking English that can be felt through the form of fluency in English, able to optimize the students speaking English, 
and the values achieved by students as a result of the learning process in schools. The result of speaking English is something obtained after performing the process of speaking English related to human grammar. In realizing good speaking results it is necessary for the presence of the proper method, one of them is using NLP method. Learning using NLP involves students with important activities that help them to connect academic learning with real life contexts they face. By linking the two, the students see the meaning in school.

From the above discussion it is clear about the notion of learning Neurolinguistics Programming (NLP), which has become a technology of mind of the most popular and used by many people in the world. NLP is a model of human excellence. Contains a set of advanced techniques and attitude for overall use of the resources of mind, mental, and physical. NLP provides the ability to change, adopt or eliminate behaviors as desired, and provide the ability to choose their own mental state, emotional, and physical condition. Based on the above description, it can be concluded that there is significant influence of NLP method against English-speaking students. The average English-speaking students taught using NLP method better than students that taught using conventional method.

\section{CONCLUSION}

This study examines the differences in English-speaking students who are taught by conventional method with the students taught with NLP method. The following conclusions will be presented as the end result of this research. Based on the interpretation and hypothesis testing, the results of research can be summarized as follows: Conditions of average English-speaking students taught using conventional method is categorized as sufficient. From the results, obtained the results of students speaking given conventional method, the average value of $\bar{Y}=43,61$ standard deviation amounted to $S_{Y}=12,83$. Meanwhile the median and mode, respectively are 40 and 35,5.

Average conditions of the results of students speaking English taught using NLP method is categorized as good. The calculation result above obtained average value of students speaking English taught using NLP method of 64.76 with a standard deviation of 9.43. Meanwhile the median and mode respectively are 63 and 58.5.

There is a positive and significant impact of students that the learning is using NLP method in the ability to speak English. For $\alpha=0.05$ and $\mathrm{df}=19$, obtained from table $t=1.73$, while $t_{\text {count }}$ $=9,26$. Thus $\mathrm{t}_{\text {count }}>\mathrm{t}_{\text {table }}$, This means that reject $\mathrm{H}_{0}$, accept $\mathrm{H}_{1}$, Thus it can be concluded, their speaking ability of NLP method affect positively and significant compared with students given conventional method. From the research results found that there are significant differences in learning method on their speaking ability. Thus, this study provides implications. First, a method is an important role in the success of students' learning. The exact method applied during the learning process will give good impact on improving student learning outcomes. Likewise, the learning process by using Neurolinguistic Programming (NLP). From the research that has been done, this method has the ability to speak better than conventional method. In addition to being a good method applied in the classroom, some of the factors that influence the ability to speak, among others: NLP has the ability to absorb the problems they encounter, NLP is to make students confident, 
especially in speaking, NLP increases the motivation to speak, and also NLP can improve performance with thoughts that run by their own brains without any encouragement.

\section{REFERENCES}

Bandler, R., \& John. (1975). The Structure of Magic I: A Book about Language and Therapy. Science and behavior Books Inc.

Brown, H. D. (2007). Principle of Language Learning. San Fransisco: State University. . (2014). Language Assessment. Longman Press.

Devilly, G. J. (2005). Power therapies and possible threats to the science of psychology and psychiatry. Australian and New Zealand Journal of Psychiatry, 39(6), 437445.

Druckman, D. (2004). Be all that you can be: enhancing human performance. Journal of Applied Social Psychology, 34(11), 22342260.

Gelso, C.J., \& Fassinger, R.E. (1990). Counseling psychology: theory and research on interventions. Annual Review of Psychology. 41(1): 355-386.

Jackson, H. (2011). An Introduction to the Nature and Functions of Language. Continuum: Australia.

Luoma, Sari. (2009). Assesing Speaking. New York: Cambridge University Press.
Masters, B. R., Rawlins, M., \& Weidner, L. J. (1991). The NLP Swish pattern: an innovative visualizing technique. Journal of Mental Health Counseling, 13(1), 79-90.

Millrood, R. (2004). The role of NLP in teacher's classroom discourse. ELT Journal, 58(1), 28-37.

Nurgiantoro, B. (1995). Penilaian dalam Pengajaran Bahasa dan Sastra: Edisi 2. Yogyakarta: BPFE.

Patel, Dr. M.F. (2008). English Language Teaching. New York: Cambridge University Press.

Richards, J. C., \& Rodgers, T.S. (2003). Approaches and Methods in Language Teaching. New York: Cambridge University Press.

Riyono, A. (2012). Teaching English communication skills with NLP. Encounter, 1(3).

Sailendra, A. (2014). Neuro-Linguistic Programming (NLP): Cetakan II. Yogyakarta: Bhafana Publishing.

Sharpley, C. F. (1987). Research findings on neurolinguistic programming: Nonsupportive data or an untestable theory? Journal of Counseling Psychology, 34(1), 103-107.

Sugiyono. (2012). Metode Penelitian Pendidikan. Bandung: Alfabeta. 